\title{
PENGARUH PERBANDINGAN TEPUNG HANJELI (Coix lacryma-Jobi, L.) DENGAN BUAH SALAK KERING (Salacca edulis Reinw.) TERHADAP KARAKTERISTIK SNACK BAR
}

The Effect of Hanjeli Flour (Coix lacryma-Jobi, L.) Ratio with Dried Snake Fruit (Salacca edulis Reinw.) to The Characteristics of Snack Bar

\author{
Ni Putu Putri Dewanty Saraswati'), I Gusti Ayu Ekawati ${ }^{2}$, I Nengah Kencana Putra ${ }^{2)}$ \\ ${ }^{1)}$ Mahasiswa Program Studi Ilmu dan Teknologi Pangan, Fakultas Teknologi Pertanian, Unud \\ ${ }^{2)}$ Dosen Program Studi Ilmu dan Teknologi Pangan, Fakultas Teknologi Pertanian, Unud \\ Kampus Bukit Jimbaran, Badung-Bali
}

\begin{abstract}
This study aims to determine the effect of hanjeli flour and dried snake fruit to the characteristics of snack bar produced and the right ratio of hanjeli flour and dried snake fruit that is able to produce snack bar with the best characteristics. The Completely Randomized Design was used in the research with treatment that is the ratio of hanjeli flour and dried snake fruit which consist of 5 levels: $90 \%: 10 \% ; 80 \%: 20 \% ; 70 \%: 30 \% ; 60 \%: 40 \% ; 50 \%: 50 \%$. The treatment was repeated 3 times to obtain 15 units of experiment. The data obtained were analyzed by variance and if the treatment had an effect on the observed variable then continued with Duncan test. The result showed that hanjeli flour and dried snake fruit had a significant effect on water content, ash content, fat content, protein content, carbohydrate content, coarse fiber content, hardness, color (hedonic), aroma (hedonic), texture (hedonic and scoring), taste (hedonic) and overall acceptance (hedonic). Comparison of $50 \%$ hanjeli flour : $50 \%$ dried snake fruit produces snack bar with the best characteristics, namely: water content $18.43 \%$, ash content $1,82 \%$, fat content $16.63 \%$, protein content $7.84 \%$, carbohydrate content $55.29 \%$, crude fiber content $3,14 \%$, calori total $402,10 \mathrm{kcal}$, color liked, aroma very liked, texture little crumbly and liked, taste liked and overall acceptance liked.
\end{abstract}

Keywords : hanjeli flour, dried snake fruit, snack bar

\section{PENDAHULUAN}

Indonesia merupakan negara dengan tingkat konsumsi camilan yang tinggi. Hasil penelitian menyebutkan, rata-rata 1 dari 3 orang Indonesia mengonsumsi lebih dari tiga jenis camilan per harinya, selain makanan pokok (Anon., 2017). Seiring meningkatnya kesadaran masyarakat dengan pola makan sehat, maka kebutuhan camilan untuk masyarakat pada saat ini diutamakan yang memiliki nilai gizi, praktis, dan kalori yang tidak berlebih seperti snack bar. Snack bar merupakan camilan berbentuk batangan yang sehat karena mengandung gizi berupa protein, karbohidrat, lemak, dan vitamin
(Christian, 2011). Snack bar diminati karena selain bergizi, camilan tersebut mengandung kalori yang rendah sehingga bagus untuk orang yang melakukan diet kalori. Snack bar cocok dikonsumsi untuk orang yang memiliki aktifitas padat dan melewatkan jam makan siang sehingga memerlukan makanan pengganjal hingga waktu santapan berikutnya. Proses pembuatan snack bar yaitu menggunakan bahan dasar serealia atau kacang-kacangan berbentuk tepung yang dipadatkan berbentuk batangan dan dipanggang (Pradipta, 2011). Proses pembuatan snack bar juga ditambahkan isian buah-buahan dan kacang-kacangan sebagai pelengkap atau penambah cita rasa.

*Korespondensi Penulis:

Email: p_dewanty@yahoo.com ${ }^{1)}$ 
Serealia yang potensial dan memiliki prospek yang baik untuk dikembangkan adalah hanjeli (Coix lacryma-Jobi, L.). Kandungan protein, lemak, dan vitamin B1 pada hanjeli lebih tinggi apabila dibandingkan beras, millet, jagung, sorghum, dan barley sehingga cocok digunakan sebagai bahan pembuatan snack bar. Kalsium (Ca) yang dikandung hanjeli lebih tinggi dibandingkan beras, jagung, dan sorghum (Grubben dan Partohardjono, 1996). Hanjeli umumnya dijadikan subtitusi beras pada musim paceklik, dan diolah menjadi bubur hanjeli gurih, tepung hanjeli, dan berbagai bahan kue. Menurut Yulianto et al. (2006) pengolahan hanjeli menjadi tepung dilakukan untuk memperpanjang daya simpan yang dapat digunakan untuk pembuatan adonan gula dan brownies. Pemanfaatan tepung hanjeli juga cocok sebagai bahan dasar pembuatan kue atau kudapan yang tidak memiliki tekstur mengembang seperti snack bar.

Pembuatan snack bar pada umumnya ditambahkan buah-buahan kering dan kacangkacangan sebagai penambah cita rasa dan menambah nilai gizi. Salah satu jenis buah yang dapat digunakan dalam pembuatan snack bar adalah salak sebagai diversifikasi pangan lokal. Salak dapat ditambahkan dalam snack bar karena selain rasa dan aromanya yang khas, salak juga mengandung serat sebanyak 3,23 mg (Hardjana et al., 2016). Kandungan mineral dalam daging buah salak meliputi kalsium $28 \mathrm{mg}$, fosfor $18 \mathrm{mg}$, besi 4,2 $\mathrm{mg}$ tiap 100 gram daging buah salak (Direktorat Gizi, 1979). Antioksidan yang terkandung pada salak adalah asam askorbat sebesar 129,34mg/100gr (Kurniawati, 2010). Salak yang digunakan dalam pembuatan snack bar berasal dari daerah Bali yang dikenal dengan salak nangka. Menurut Anon., (2018) produksi salak di Bali pada tahun 2015 mencapai 27.204 ton. Penjualan salak di pasaran umumnya dikelompokan sesuai kualitas sehingga kualitas terendah mengalami penurunan nilai jual, untuk itu salak diolah agar meningkatkan nilai jual. Menurut Monoarfa (1976) untuk memperpanjang umur simpan salak dapat dilakukan proses pengeringan terlebih dahulu sehingga dapat ditambahkan pada snack bar.

\section{METODE PENELITIAN}

\section{Tempat dan Waktu}

Penelitian ini dilaksanakan di laboratorium Pengolahan Pangan, laboratorium Analisis Pangan, dan laboratorium Rekayasa Proses dan Pengendalian Mutu, Fakultas Teknologi Pertanian, Universitas Udayana, Denpasar. Penelitian ini dilaksanakan dari bulan Mei 2018 sampai dengan Juni 2018.

\section{Bahan dan Alat}

Bahan-bahan yang digunakan dalam penelitian ini terdiri dari bahan baku, bahan tambahan, dan bahan kimia. Bahan baku terdiri dari hanjeli dan buah salak bali varietas nangka. Hanjeli, dan kacang tanah yang digunakan diperoleh dari supermarket Tiara Dewata, Denpasar. Salak bali varietas nangka diperoleh di pasar Badung, Denpasar. Bahan tambahan terdiri dari margarin merk Blue Band, gula halus, telur, garam diperoleh dari UD.Fenny, dan maltodekstrin diperoleh dari Bratachem, Denpasar. Bahan kimia yang digunakan dalam melakukan analisis proksimat dan analisis serat kasar meliputi $\mathrm{H}_{2} \mathrm{SO}_{4}, \mathrm{NaOH}, \mathrm{HCl}$, Heksan, alkohol 95\%, tablet Kjeldahl, aquades, asam borat, dan indikator PP.

Alat yang digunakan untuk membuat snack bar adalah meja, waskom, ayakan 80 mesh, solet, loyang, blender, timbangan digital, kuas, oven, pisau, talenan. Alat yang digunakan untuk analisis sifat fisik dan kimia adalah kertas saring, timbagan analitik, erlenmeyer, cawan porselin, tabung reaksi, batang pengaduk, desikator, corong, pipet tetes, labu takar, aluminium foil, pinset, biuret, muffle, oven, pompa karet, destilator, gelas ukur, gelas beaker, pipet volume, labu kjeldahl, soxhlet, 
waterbath, kertas whatman 42. Selain itu untuk evaluasi sensoris produk, alat yang digunakan adalah piring kertas dan label.

\section{Rancangan Percobaan}

Penelitian ini dilakukan dengan menggunakan Rancangan Acak Lengkap (RAL), dengan perlakuan perbandingan konsentrasi tepung hanjeli dengan buah salak kering yang digunakan pada pembuatan snack bar, yaitu :P1 (90\%:10\%), P2 (80\%:20\%), P3 (70\%:30\%), P4 (60\%:40\%), P5 (50\%: 50\%). Masing-masing perlakuan diulang sebanyak 3 kali sehingga diperoleh 15 unit percobaan. Data yang diperoleh dari hasil penelitian dianalisis dengan sidik ragam (ANOVA) dan apabila perlakuan berpengaruh terhadap variabel maka dilanjutkan dengan uji Duncan's Multiple Range Test (DMRT) (Gomez dan Gomez, 1995).

\section{Pelaksanaan Penelitian}

Pembuatan snack bar perbandingan tepung hanjeli dengan buah salak kering terdiri dari 3 tahap. Tahap I adalah pembuatan tepung hanjeli. Pembuatan tepung hanjeli mengacu pada Fitriyani dan Romadini (2013) yang dimodifikasi pada proses pencucian dan pengeringan. Biji hanjeli dengan ukuran yang kecil dicuci bersih menggunakan air mengalir. Biji ditiriskan dibawah sinar matahari selama \pm 10 menit hingga kering. Biji dihancurkan menggunakan blender, kemudian diayak menggunakan ayakan 80 mesh.

Tahap II adalah pembuatan buah salak kering. Pembuatan buah salak kering mengacu pada Siregar (2017). Buah salak disortir dan dikupas kulitnya, kemudian buah dipisahkan dari bijinya dan dipotong-potong berbentuk dadu $\pm 5 \times 5 \mathrm{~mm}$. Buah salak dikeringkan di dalam oven pada suhu $60^{\circ} \mathrm{C}$ selama 4,5 jam sehingga diperoleh buah salak kering. Adapun formula snack bar perbandingan tepung hanjeli dengan salak kering dapat dilihat pada Tabel 1.

Tabel 1. Formula snack bar

\begin{tabular}{|c|c|c|c|c|c|}
\hline \multirow{2}{*}{ Komposisi } & \multicolumn{5}{|c|}{ Perlakuan } \\
\hline & $\mathrm{P} 1$ & $\mathrm{P} 2$ & P3 & $\mathrm{P} 4$ & P5 \\
\hline Tepung hanjeli (\%) & 90 & 80 & 70 & 60 & 50 \\
\hline Salak kering (\%) & 10 & 20 & 30 & 40 & 50 \\
\hline Kacang tanah $(\%)$ & 10 & 10 & 10 & 10 & 10 \\
\hline Telur (\%) & 60 & 60 & 60 & 60 & 60 \\
\hline Gula halus (\%) & 10 & 10 & 10 & 10 & 10 \\
\hline Margarin (\%) & 10 & 10 & 10 & 10 & 10 \\
\hline Garam (\%) & 1 & 1 & 1 & 1 & 1 \\
\hline Maltodekstrin (\%) & 1 & 1 & 1 & 1 & 1 \\
\hline
\end{tabular}

Keterangan : Persentase berdasarkan jumlah campuran tepung hanjeli dan buah salak kering (100 g)

Tahap III adalah pembuatan snack bar perbandingan tepung hanjeli dengan buah salak kering. Pembuatan snack bar Proses pembuatan snack bar mengacu pada Pradipta (2011), yang dimodifikasi pada tahap pencampuran. Pencampuran tahap pertama margarin, gula halus, garam, dan maltodekstrin dikocok hingga rata. Setelah tercampur dilakukan penambahan telur diaduk hingga rata. Tepung hanjeli dan buah kering (sesuai perlakuan) ditambahkan secara bersamaan kedalam adonan dengan penambahan kacang tanah. Adonan dicetak ke dalam loyang kemudian dipanggang ke dalam oven dengan suhu $120^{\circ} \mathrm{C}$ selama 60 menit (berwarna kecoklatan).

\section{Variabel yang Diamati}

Variabel yang diamati dalam penelitian ini meliputi kadar air dilakukan dengan metode pengeringan (Sudarmadji et al., 1997), kadar abu dilakukan dengan menggunakan metode 
pengabuan (Sudarmadji et al., 1997), kadar lemak dilakukan dengan menggunakan metode Soxhlet (Sudarmadji et al., 1997), kadar protein dilakukan dengan menggunakan metode Mikro-Kjeldahl (Sudarmadji et al., 1997), kadar karbohidrat dilakukan dengan metode Carbohydrate by different (Sudarmadji et al., 1997), kadar serat kasar dilakukan dengan metode hidrolisis asam basa (Sudarmadji et al., 1997), total kalori dengan metode perhitungan kalori hasil analisis proksimat (Handa et al., 2012), dan sifat sensoris yang meliputi warna, tekstur, rasa, aroma, dan penerimaan keseluruhan (Soekarto, 1985).

\section{HASIL DAN PEMBAHASAN}

Hasil analisis kadar air, kadar abu, kadar lemak, kadar protein, kadar karbohidrat dan kadar serat kasar dari tepung hanjeli dan buah salak kering yang digunakan dapat dilihat pada Tabel 2. Hasil analisis proksimat (kadar air, kadar abu, kadar lemak, kadar protein, kadar karbohidrat), kadar serat kasar dan total kalori dari snack bar terdapat pada Tabel 3.

\section{Kadar Air}

Hasil sidik ragam menunjukkan bahwa perbandingan tepung hanjeli dengan buah salak kering berpengaruh sangat nyata $(\mathrm{P}<0,01)$ terhadap kadar air snack bar. Tabel 8 menunjukkan kadar air snack bar berkisar antara $14,28 \%$ sampai dengan $18,43 \%$. Kadar air snack bar tertinggi diperoleh dari snack bar pada perlakuan P5 yaitu 18,43\%, sedangkan kadar air snack bar terendah diperoleh dari snack bar pada perlakuan P1 yaitu 14,28\% serta berbeda tidak nyata dengan perlakuan P2.

Pembuatan snack bar dengan penambahan buah salak kering yang semakin meningkat menghasilkan snack bar dengan kadar air yang semakin tinggi. Hal ini disebabkan karena kadar air buah salak kering lebih tinggi dari tepung hanjeli. Berdasarkan analisis bahan baku (Tabel 7) kadar air buah salak kering adalah 19,57\%, sedangkan kadar air tepung hanjeli adalah $8,37 \%$.

\section{Kadar Abu}

Hasil sidik ragam menunjukkan bahwa perbandingan tepung hanjeli dengan buah salak kering berpengaruh sangat nyata $(\mathrm{P}<0,01)$ terhadap kadar abu snack bar. Kadar abu snack bar tertinggi diperoleh pada perlakuan P5 yaitu 1,82\% serta berbeda tidak nyata dengan perlakuan $\mathrm{P} 4$, sedangkan kadar abu terendah diperoleh pada perlakuan P1 yaitu $1,50 \%$ serta berbeda tidak nyata dengan perlakuan P2 dan P3.

Semakin banyak penggunaan buah salak kering maka kadar abu snack bar yang dihasilkan semakin meningkat. Hal ini disebabkan buah salak kering memiliki kadar abu yang lebih tinggi dibandingkan dengan tepung hanjeli, dimana kadar abu buah salak kering sebesar 2,13\% sedangkan tepung hanjeli sebesar $0,99 \%$.

\section{Kadar Lemak}

Hasil sidik ragam menunjukkan bahwa perbandingan tepung hanjeli dengan buah salak kering berpengaruh sangat nyata $(\mathrm{P}<0,01)$ terhadap kadar lemak snack bar. Kadar lemak snack bar tertinggi diperoleh pada perlakuan P1 yaitu 21,42\%. Kadar lemak terendah diperoleh pada perlakuan P5 yaitu $16,63 \%$ serta berbeda tidak nyata dengan perlakuan P4. Kandungan lemak snack bar mengalami penurunan dengan semakin banyak buah salak kering. Hal ini disebabkan kandungan lemak buah salak kering lebih rendah dibandingkan dengan kandungan tepung hanjeli, kandungan lemak buah salak kering sebesar $0,10 \%$ sedangkan tepung hanjeli memiliki kandungan lemak sebesar 3,24\%. Menurut Janah (2017), besarnya nilai kadar lemak pada produk snack bar komersial berkisar antara 12,1-16,7\% sehingga snack bar pada perlakuan P5 dapat menyamai snack bar komersial 
Tabel 2. Nilai rata-rata hasil analisis proksimat (kadar air, kadar abu, kadar lemak, kadar protein, kadar karbohidrat) dan kadar serat kasar dari tepung hanjeli dan buah salak kering

\begin{tabular}{lcc}
\hline \multicolumn{1}{c}{ Komponen } & Tepung Hanjeli & Buah Salak Kering \\
\hline Air (\%) & 8,37 & 19,57 \\
Abu (\%) & 0,99 & 2,13 \\
Lemak (\%) & 3,24 & 0,10 \\
Protein (\%) & 10,62 & 0,24 \\
Karbohidrat (\%) & 76,78 & 77,95 \\
Serat Kasar (\%) & 1,43 & 3,72 \\
\hline
\end{tabular}

Tabel 3. Nilai rata-rata hasil analisis proksimat (kadar air, kadar abu, kadar lemak, kadar protein, kadar karbohidrat), kadar serat kasar dan total kalori dari snack bar

\begin{tabular}{cccccccc}
\hline $\begin{array}{c}\text { Perlakuan (Tepung } \\
\text { Hanjeli : Buah Salak } \\
\text { Kering) }\end{array}$ & $\begin{array}{c}\text { Kadar } \\
\text { Air }(\%)\end{array}$ & $\begin{array}{c}\text { Kadar Abu } \\
(\%)\end{array}$ & $\begin{array}{c}\text { Kadar } \\
\text { Lemak } \\
(\%)\end{array}$ & $\begin{array}{c}\text { Kadar } \\
\text { Protein } \\
(\%)\end{array}$ & $\begin{array}{c}\text { Kadar } \\
\text { Karbohidrat } \\
(\%)\end{array}$ & $\begin{array}{c}\text { Kadar Serat } \\
\text { Kasar }(\%)\end{array}$ & $\begin{array}{c}\text { Total } \\
\text { Kalori } \\
(\text { Kkal) }\end{array}$ \\
\hline \multirow{2}{*}{ P1 $(90 \%: 10 \%)$} & $14,28 \pm$ & $1,50 \pm$ & $21,42 \pm$ & $11,64 \pm$ & $51,16 \pm$ & $1,94 \pm$ & $443,97 \pm$ \\
& $0,4021 \mathrm{c}$ & $0,0506 \mathrm{c}$ & $0,4439 \mathrm{a}$ & $0,5644 \mathrm{a}$ & $1,6375 \mathrm{c}$ & $0,8107 \mathrm{~b}$ & $3,7026 \mathrm{a}$ \\
\hline \multirow{2}{*}{ P2 $(80 \%: 20 \%)$} & $15,02 \pm$ & $1,56 \pm$ & $19,64 \pm$ & $10,61 \pm$ & $53,16 \pm$ & $2,03 \pm$ & $431,88 \pm$ \\
& $0,3922 \mathrm{c}$ & $0,1615 \mathrm{c}$ & $0,6561 \mathrm{~b}$ & $0,3129 \mathrm{~b}$ & $1,6211 \mathrm{~b}$ & $0,1572 \mathrm{~b}$ & $4,6655 \mathrm{~b}$ \\
\hline \multirow{2}{*}{ P3 (70\%: 30\%) } & $16,82 \pm$ & $1,66 \pm$ & $18,50 \pm$ & $9,14 \pm$ & $53,89 \pm$ & $2,20 \pm$ & $418,59 \pm$ \\
& $0,1683 \mathrm{~b}$ & $0,0340 \mathrm{bc}$ & $0,3329 \mathrm{c}$ & $0,7388 \mathrm{c}$ & $1,5126 \mathrm{~b}$ & $0,2634 \mathrm{ab}$ & $1,1381 \mathrm{c}$ \\
\hline \multirow{2}{*}{ P4 $(60 \%: 40 \%)$} & $17,45 \pm$ & $1,78 \pm$ & $17,51 \pm$ & $8,23 \pm$ & $55,04 \pm$ & $3,06 \pm$ & $410,72 \pm$ \\
& $0,5689 \mathrm{~b}$ & $0,0825 \mathrm{ab}$ & $0,3182 \mathrm{~cd}$ & $0,1388 \mathrm{~d}$ & $2,1685 \mathrm{a}$ & $0,7078 \mathrm{a}$ & $3,0563 \mathrm{c}$ \\
\hline \multirow{2}{*}{ P5 (50\%: 50\%) } & $18,43 \pm$ & $1,82 \pm$ & $16,63 \pm$ & $7,84 \pm$ & $55,29 \pm$ & $3,14 \pm$ & $402,10 \pm$ \\
& $0,6997 \mathrm{a}$ & $0,0319 \mathrm{a}$ & $0,8474 \mathrm{~d}$ & $0,2257 \mathrm{~d}$ & $0,9824 \mathrm{a}$ & $0,1322 \mathrm{a}$ & $6,9949 \mathrm{~d}$ \\
\hline
\end{tabular}

Keterangan : Nilai rata - rata yang diikuti oleh huruf yang berbeda pada kolom yang sama menunjukkan perbedaan yang nyata pada Uji Duncan $(\mathrm{P}<0,05)$

\section{Kadar Protein}

Semakin meningkat jumlah tepung hanjeli yang digunakan, maka kadar protein snack bar yang dihasilkan juga semakin meningkat. Peningkatan kandungan protein ini dikarenakan kandungan protein tepung hanjeli lebih tinggi yaitu sebesar $10,62 \%$ dibandingkan buah salak kering yang hampir tidak memiliki kandungan protein yaitu sebesar 0,24\%. Menurut Siregar (2017), besarnya nilai kadar protein pada produk snack bar komersial berkisar antara 10-15\% sehingga snack bar pada perlakuan P1 dan P2 dapat menyamai snack bar komersial.

\section{Kadar Karbohidrat}

Hasil sidik ragam menunjukkan bahwa perbandingan tepung hanjeli dengan buah salak kering berpengaruh sangat nyata $(\mathrm{P}<0,01)$ terhadap kadar karbohidrat snack bar. Kadar Karbohidrat snack bar tertinggi diperoleh pada perlakuan P5 yaitu 55,29\% serta berbeda tidak nyata dengan perlakuan P4. Kadar karbohidrat terendah diperoleh pada perlakuan P1 yaitu 51,16\%.

Kandungan karbohidrat snack bar mengalami penurunan dengan semakin banyak penggunaan tepung hanjeli. Kandungan karbohidrat buah salak kering 77,95\%, lebih tinggi dibandingkan tepung hanjeli yang hanya $76,78 \%$. Kadar karbohidrat yang dihitung secara Carbohydrate by different artinya kandungan tersebut dari hasil pengurangan angka 100 dengan persentasi komponen lain yaitu kadar air, kadar abu, kadar protein, dan kadar lemak (Siregar, 2017). Semakin rendah komponen lain maka kadar karbohidrat akan semakin tinggi.

\section{Kadar Serat Kasar}

Hasil sidik ragam menunjukkan bahwa 
substitusi perbandingan tepung hanjeli dengan buah salak kering berpengaruh nyata $(\mathrm{P}<0,05)$ terhadap kadar serat kasar snack bar yang dihasilkan. Kadar serat kasar snack bar tertinggi diperoleh pada perlakuan P5 yaitu $3,14 \%$, serta berbeda tidak nyata dengan perlakuan P3 dan P4. Kadar serat kasar terendah diperoleh pada perlakuan P1 yaitu $1,94 \%$. Peningkatan kadar serat kasar ini seiring dengan peningkatan penggunaan buah salak kering, karena buah salak kering memiliki kandungan serat kasar yang lebih tinggi yaitu $3,72 \%$ dibandingkan dengan tepung hanjeli yang hanya memiliki kadar serat kasar $1,43 \%$.

\section{Total Kalori}

Hasil sidik ragam menunjukkan bahwa perbandingan tepung hanjeli dengan buah salak kering berpengaruh sangat nyata $(\mathrm{P}<0,01)$ terhadap total kalori snack bar. Total kalori snack bar tertinggi diperoleh pada perlakuan $\mathrm{P} 1$ yaitu 443,97 kkal/100 gram berat snack bar, sedangkan total kalori terendah diperoleh pada perlakuan P5 yaitu 402,10 $\mathrm{kkal} / 100$ gram berat snack bar. Menurut Ladamay dan Yuwono (2014), total kalori snack bar komersial (soy joy) sebesar 466,67 $\mathrm{kkal} / 100$ gram berat snack bar sehingga total kalori snack bar pada penelitian ini dapat lebih rendah dari snack bar komersial.

Berdasarkan Angka Kecukupan Gizi (AKG) yang biasa tertera pada snack bar di pasaran, kandungan zat gizi per sajian makanan selingan sebesar 10\% dari kebutuhan kalori sehari (AKG 2000 kkal/hari). Berat per sajian snack bar pada penelitian ini adalah 30gram. Total kalori per sajian pada perlakuan
P1 sebesar 130,19 kkal, P2 sebesar 129,56 kkal, P3 sebesar 125,58 kkal, P4 sebesar 123,22 kkal, dan P5 sebesar 120,63 kkal. Penyajian produk snack bar pada penelitian ini disarankan sebanyak 2 buah dalam sekali santap untuk memenuhi kebutuhan energi dalam sehari.

\section{Evaluasi Sifat Sensoris}

Nilai rata-rata uji hedonik terhadap warna, aroma, tekstur, rasa dan penerimaan keseluruhan snack bar dapat dilihat pada Tabel 5 dan nilai rata-rata uji skoring tesktur pada Tabel 6.

\section{Warna}

Hasil sidik ragam menunjukkan bahwa perbandingan tepung hanjeli dengan buah salak kering berpengaruh sangat nyata $(\mathrm{P}<0,01)$ terhadap warna snack bar. Tabel 5 menunjukkan bahwa nilai rata-rata tertinggi diperoleh dari snack bar perlakuan P5 yaitu suka dan berbeda tidak nyata dengan P4 sedangkan nilai rata-rata terendah diperoleh dari snack bar pada perlakuan P1 yaitu biasa.
Aroma
Hasil sidik ragam menunjukkan bahwa perbandingan tepung hanjeli dengan buah salak kering berpengaruh sangat nyata $(\mathrm{P}<0,01)$ terhadap kesukaan aroma (uji hedonik) snack bar. Tabel 5 menunjukkan bahwa nilai rata-rata tingkat kesukaan panelis terhadap aroma tertinggi diperoleh dari snack bar pada perlakuan P5 yaitu sangat suka dan berbeda tidak nyata dengan $\mathrm{P} 4$ sedangkan nilai rata-rata terendah diperoleh dari snack bar pada perlakuan P1 yaitu agak suka. 
Tabel 5. Nilai rata-rata uji hedonik warna, aroma, tekstur, rasa dan penerimaan keseluruhan snack bar

\begin{tabular}{cccccc}
\hline \multirow{2}{*}{ Perlakuan } & \multicolumn{5}{c}{ Nilai rata - rata uji hedonik } \\
\cline { 2 - 6 } & Warna & Aroma & Tekstur & Rasa & $\begin{array}{c}\text { Penerimaan } \\
\text { Keseluruhan }\end{array}$ \\
\hline P1 & $3,60 \pm 0,821 \mathrm{~d}$ & $4,60 \pm 0,821 \mathrm{~d}$ & $4,40 \pm 0.995 \mathrm{~b}$ & $4,00 \pm 0,918 \mathrm{~d}$ & $4,40 \pm 0,883 \mathrm{c}$ \\
\hline P2 & $4,50 \pm 0,889 \mathrm{c}$ & $5,20 \pm 0,951 \mathrm{c}$ & $4,60 \pm 0,883 \mathrm{~b}$ & $4,70 \pm 0,979 \mathrm{c}$ & $4,75 \pm 0,716 \mathrm{c}$ \\
\hline P3 & $5,55 \pm 0,686 \mathrm{~b}$ & $6,00 \pm 0,324 \mathrm{~b}$ & $5,75 \pm 0,967 \mathrm{a}$ & $5,65 \pm 0,988 \mathrm{~b}$ & $5,75 \pm 0,910 \mathrm{~b}$ \\
\hline P4 & $6,35 \pm 0,489 \mathrm{a}$ & $6,35 \pm 0,587 \mathrm{ab}$ & $6,15 \pm 0,489 \mathrm{a}$ & $6,15 \pm 0,671 \mathrm{ab}$ & $6,15 \pm 0,489 \mathrm{ab}$ \\
\hline P5 & $6,40 \pm 0,598 \mathrm{a}$ & $6,50 \pm 0,761 \mathrm{a}$ & $5,95 \pm 0,605 \mathrm{a}$ & $6,35 \pm 0,671 \mathrm{a}$ & $6,35 \pm 0,875 \mathrm{a}$ \\
\hline
\end{tabular}

Keterangan : Nilai rata - rata yang diikuti oleh huruf yang berbeda pada kolom yang sama menunjukkan perbedaan yang nyata pada Uji Duncan $(\mathrm{P}<0,05)$

Kriteria hedonik : 1 (sangat tidak suka), 2 (tidak suka), 3 (agak tidak suka), 4 (biasa), 5 (agak suka), 6 (suka), 7 (sangat suka)

Tabel 6. Nilai rata-rata uji skoring tekstur snack bar.

\begin{tabular}{ccc}
\hline \multirow{2}{*}{$\begin{array}{c}\text { Perlakuan } \\
\end{array}$} & $\begin{array}{c}\text { Perbandingan tepung hanjeli dengan buah salak } \\
\text { kering }\end{array}$ & Nilai rata - rata uji skoring \\
\cline { 2 - 3 } P1 & $90 \%: 10 \%(\mathrm{P} 1)$ & Tekstur \\
\hline P2 & $80 \%: 20 \%(\mathrm{P} 2)$ & $3,55 \pm 0,510 \mathrm{a}$ \\
\hline P3 & $70 \%: 30 \%(\mathrm{P} 3)$ & $3,75 \pm 0,394 \mathrm{~b}$ \\
\hline P4 & $60 \%: 40 \%(\mathrm{P} 4)$ & $3,60 \pm 0,598 \mathrm{~b}$ \\
\hline P5 & $50 \%: 50 \%(\mathrm{P} 5)$ & $3,00 \pm 0,649 \mathrm{c}$ \\
\hline
\end{tabular}

Keterangan : Nilai rata - rata yang diikuti oleh huruf yang berbeda pada kolom yang sama menunjukkan perbedaan yang nyata pada Uji Duncan 0,05

Nilai skoring tekstur : 1 (sangat rapuh); 2 (rapuh); 3 (agak rapuh) ; 4 (empuk); 5 (sangat empuk)

\section{Tekstur}

Hasil sidik ragam menunjukkan bahwa perbandingan tepung hanjeli dengan buah salak kering berpengaruh sangat nyata $(\mathrm{P}<0,01)$ terhadap tekstur (uji hedonik) snack bar. Tabel 5 menunjukkan bahwa nilai ratarata tingkat kesukaan panelis terhadap tekstur tertinggi diperoleh dari snack bar pada perlakuan P4 yaitu suka dan berbeda tidak nyata dengan perlakuan P3, dan P5 sedangkan nilai rata-rata tekstur snack bar terendah diperoleh pada perlakuan P1 yaitu biasa dan berbeda tidak nyata dengan P2.

Hasil sidik ragam menunjukkan bahwa perbandingan tepung hanjeli dengan buah salak kering berpengaruh sangat nyata $(\mathrm{P}<0,01)$ terhadap tekstur (uji skoring) snack bar. Tabel 6 menunjukkan bahwa nilai ratarata penerimaan terhadap tekstur (uji skoring) tertinggi snack bar diperoleh pada perlakuan P1 yaitu sangat empuk, sedangkan nilai ratarata terendah snack bar diperoleh pada perlakuan P5 yaitu agak rapuh.

\section{Rasa}

Hasil sidik ragam menunjukkan bahwa perbandingan tepung hanjeli dengan buah salak kering berpengaruh sangat nyata $(\mathrm{P}<0,01)$ terhadap rasa snack bar. Tabel 5 menunjukkan bahwa nilai rata-rata tertinggi kesukaan panelis terhadap rasa snack bar diperoleh pada perlakuan P5 yaitu suka sedangkan nilai rata-rata terendah diperoleh pada perlakuan P1 yaitu biasa.

\section{Penerimaan Keseluruhan}

Hasil sidik ragam menunjukkan bahwa perbandingan tepung hanjeli dengan buah salak kering berpengaruh sangat nyata $(\mathrm{P}<0,01)$ terhadap penerimaan keseluruhan snack bar. Tabel 5 menunjukkan bahwa nilai rata-rata tertinggi kesukaan panelis terhadap penerimaan keseluruhan snack bar diperoleh pada perlakuan $\mathrm{P} 4(60 \%$ tepung hanjeli dan 
$40 \%$ buah salak kering) yaitu suka sedangkan nilai rata-rata terendah diperoleh pada perlakuan P1 (90\% tepung hanjeli dan 10\% buah salak kering) yaitu biasa dan berbeda tidak nyata dengan perlakuan P2. Penerimaan keseluruhan snack bar dipengaruhi oleh beberapa faktor seperti warna, aroma, tekstur dan rasa.

\section{SIMPULAN DAN SARAN}

\section{Simpulan}

1. Perbandingan tepung hanjeli dengan buah salak kering berpengaruh terhadap kadar air, kadar abu, kadar lemak, kadar protein, kadar karbohidrat, kadar serat kasar, warna (uji hedonik), aroma (uji hedonik), tekstur (uji hedonik dan skoring), rasa (uji hedonik) serta penerimaan keseluruhan (uji hedonik) snack bar.

2. Perlakuan perbandingan $50 \%$ tepung hanjeli dengan $50 \%$ buah salak kering menghasilkan snack bar dengan karakteristik terbaik yaitu: kadar air 18,43\%, kadar abu 1,82\%, kadar lemak $16,63 \%$, kadar protein $7,84 \%$, kadar karbohidrat 55,29\%, kadar serat kasar 3,14\%, total kalori 402,10 kkal/100gram, warna disukai, aroma sangat disukai, tekstur agak rapuh dan disukai, rasa disukai serta penerimaan keseluruhan disukai.

\section{Saran}

1. Berdasarkan hasil penelitian disarankan untuk membuat snack bar perbandingan tepung hanjeli dengan buah salak kering terbaik menggunakan perbandingan $50 \%$ tepung hanjeli dengan $50 \%$ buah salak kering.

2. Konsumsi snack bar perlakuan terbaik pada penelitian ini disarankan sebanyak 2 buah potong snack bar berukuran 30 gram dengan kalori per potong sebesar 120,63 kkal untuk dapat memenuhi kebutuhan kalori melalui camilan dalam sehari.
Berdasarkan Angka Kecukupan Gizi (AKG) yang biasa tertera pada snack bar di pasaran.

\section{DAFTAR PUSTAKA}

Anonimus. 2017. Riset: 1 dari 3 Orang Indonesia Masuk Kategori 'Tukang Ngemil'. Error! Hyperlink reference not valid.. Jakarta. Diakses tanggal 5 April 2018.

Anonimus. 2018. Produksi (ton) Buah Salak Dirinci Menurut Kabupaten/Kota di Bali, 20111015.www.bali.bps.go .id. Bali. Diakses tanggal 5 Januari 2018.

Christian, M. 2011. Pengolahan banana bars dengan inulin sebagai alternatif pangan darurat. Skripsi. Fakultas Teknologi Pertanian Institut Pertanian Bogor. Bogor.

Direktorat Gizi Departemen Kesehatan Republik Indonesia. 1979. Daftar Komposisi Bahan Makanan. Bharata Karya Aksara. Jakarta.

Fitriyani dan Romadini. 2013. Studi awal Proses Fermentasi Etanol dari Tepung Hanjeli (Coix lacrma-jobi L.) dengan Menggunakan Metode VHG. http://repository.unpar.ac.id/handle/1234 56789/4158. Diakses pada tanggal 17 Januari 2018.

Gomez, K.A. dan A. A. Gomez. 1995. Prosedur Statistik Untuk Penelitian Pertanian. Universitas Indonesia Press, Jakarta.

Grubben, G. J. H., dan S. Partohardjono. 1996. Plant Resources of South - East Asia. Prosea. Bogor.

Handa, C., Goomer, S., dan Siddhu, A. 2012. Physicochemical properties and sensory 
evaluation of fructoligosaccharide enriched cookies. J Food Sci Technol. 49(2): $192-199$.

Hardjana, T., Pertiwi, K. R., dan Rahayu, T. 2016. Potensi buah salak (Salacca edulis, R.) sebagai suplemen hipolipidemik ditinjau dari gambaran histopatologi jantung dan hepar mencit yang diberi diet rendah lemak. Jurnal Sains Dasar, 5(2), 94-106.

Janah, L. N. 2017. Formulasi Torsang Snack Bar: Tepung Pisang Dan Kacang Hijau Dengan Penambahan Torbangun Sebagai Upaya Meringankan Keluhan Sindrom Pramenstruasi.

http://repository.ipb.ac.id/h andle/123456789/83685. Diakses pada tanggal 1 Juli 2018.

Kurniawati,m D. 2010. Komponen Bioaktif dan Kapasitas Antioksidan Buah Salak (Salacca Edulis Reinw) Kultivar Pondoh, Nglumut dan Bali. Skripsi. Program Studi Teknologi Hasil Pertanian. Fakultas Pertanian. Universitas Sebelas Maret. Surakarta.

Ladamay, N.A. dan Yuwono, S.S. 2014. Pemanfaatan bahan lokal dalam pembuatan foodbars (kajian rasio tapioka : tepung kacang hijau dan proporsi cmc). Jurnal Pangan dan Agroindustri Vol.2 No.1 P.67-78. Universitas Brawijaya Malang, Malang.

Monoarfa, B. 1976. Beberapa perubahan fisiko kimia dari buah salak (Salacca edulis Reinw.) selama penyimpanan suhu ruang. Laporan Masalah Khusus Fatemata. Institut Pertanian Bogor. Bogor. Hal. 14.

Pradipta, I. 2011. Karakteristik fisikokimia dan sensoris snack bar tempe dengan penambahan salak pondoh kering.
Skripsi. Program Studi Teknologi Hasil Pertanian Fakultas Pertanian Universitas Sebelas Maret. Surakarta.

Siregar, L. 2017. Pemanfaatan tepung kacang merah dan salak padang sidimpudan (Salacca sumatrana R.) dalam pembuatan snack bar. JOM Faperta UR Vol 4. Pekanbaru.

Soekarto, S.T. 1985. Penilaian Organoleptik Untuk Industri Pangan dan Pertanian. Bharata Karya Aksara : Jakarta.

Sudarmadji, S., B. Haryono dan Suhardi. 1997. Prosedur Analisa untuk Bahan Makanan dan Pertanian. Penerbit Liberty : Yogyakarta.

Yulianto Fiky, Yustanto, dan A. Suprapto. 2006.Pengembangan Plasma Nuftah Hanjeli Sebagai Pangan Potensial Berbasis Tepung di Pluncut Kabupaten Bandung. Laporan PKM UNPAD. 